\title{
Fungal Mitochondrial DNases: Effectors with the Potential to Activate Plant Defenses in Nonhost Resistance
}

\author{
Lee A. Hadwiger and James Polashock
}

First author: Department of Plant Pathology, 100 Dairy Road, Washington State University, Pullman 99164-6430; and second author: Marucci Center for Blueberry and Cranberry Research and Extension, 125A Lake Oswego Road, Chatsworth, NJ 08019. Accepted for publication 28 August 2012.

\section{ABSTRACT}

Hadwiger, L. A., and Polashock, J. 2013. Fungal mitochondrial DNases: Effectors with the potential to activate plant defenses in nonhost resistance. Phytopathology 103:81-90.

Previous reports on the model nonhost resistance interaction between Fusarium solani $\mathrm{f}$. sp. phaseoli and pea endocarp tissue have described the disease resistance-signaling role of a fungal DNase1-like protein. The response resulted in no further growth beyond spore germination. This $F$. solani f. sp. phaseoli DNase gene, constructed with a pathogenesis-related (PR) gene promoter, when transferred to tobacco, generated resistance against Pseudomonas syringe pv. tabaci. The current analytical/ theoretical article proposes similar roles for the additional nuclear and mitochondrial nucleases, the coding regions for which are identified in newly available fungal genome sequences. The amino acid sequence homologies within functional domains are conserved within a wide array of fungi. The potato pathogen Verticillium dahliae nuclease was divergent from that of the saprophyte, yeast; however, the purified DNase from yeast also elicited nonhost defense responses in pea, including pisatin accumulation, PR gene induction, and resistance against a true pea pathogen. The yeast mitochondrial DNase gene (open reading frame) predictably codes for a signal peptide providing the mechanism for secretion. Mitochondrial DNase genes appear to provide an unlimited source of components for developing transgenic resistance in all transformable plants.
There is currently an interest in applications related to "genome-enabled analyses of plant-pathogen interactions" $(28,29)$. The benefits can now be derived from known sequences of both host and pathogen. This article demonstrates the use of current fungal sequence data banks and the SignalP program (SignalP 3.0 server, Technical University of Denmark) (2) in evaluating the universality and potential of DNases in signaling nonhost resistance responses. Nonhost resistance has been described as a response elicited by an "inappropriate pathogen"; thus, not one normally considered a true pathogen of a particular host plant species (9). In comparison with race-specific resistance, nonhost resistance is seldom overcome by a fungal pathogen over time. Though the effectiveness of genes controlling nonhost resistance can be readily demonstrated, the identification of the individual contributing genes through conventional genetics is problematic. The recognition of eliciting components such as the fungal DNase enzyme contributes to the understanding of the induced plant suppression of the "inappropriate" pathogen. At the biochemical level, the DNases released by plant pathogens are readily detected on the basis of catalytic activity when fungi are grown on DNAcontaining agar or in a defined liquid media (23) in shake cultures $(6,11,19,24)$. These DNases have been proposed as signals in the activation of nonhost resistance (12). The current availability of completed genome sequences of an array of fungal plant pathogens enables both the comparison of these predicted DNase genes and their potential to be secreted from the fungal cell. Such information was initially obtained starting from compilations

Corresponding author: L. A. Hadwiger; E-mail address: chitosan@wsu.edu

* The $e$-Xtra logo stands for "electronic extra" and indicates that Figures 6 and 7 appear in color online.

http://dx.doi.org/10.1094/PHYTO-04-12-0085-R

This article is in the public domain and not copyrightable. It may be freely reprinted with customary crediting of the source. The American Phytopathological Society, 2013. of the Broad Institute, Verticillium group (http://www.broadinstitute.org/annotation/genome/verticillium_dahliae/MultiHome. html) and "Puccinia working groups". A search therein for "DNase" provided accession numbers for Verticillium dahliadeoxyribonuclease TatD, accession, VDAG_04044.1 and a $V$. dahliae mitochondrial nuclease, accession, VDAG_06446.1. These sequences and those derived from the cloning and sequencing of the Fusarium solani-sourced $F$. solani f. sp. phaseoli DNase (accession number AF175291) provided a link to subsequent National Center for Biotechnology Information (NCBI) BLAST analyses of homologous proteins from all fungi sequenced to date. The Nectria haematococca (Anan. F. solani $\mathrm{f}$. sp. pisi) mating population VI that has been sequenced by the DOE Joint Genome Institute (7) also contains predicted sequences of fungal DNases and is available online. Comparisons from these programs should assist the understanding of the basis of "nonhost resistance", a defense response that is activated by most of the fungi that come in contact with plants. These comparisons can also predict, on the basis of conserved sequence homologies, functional designations for proteins previously known only as "hypothetical proteins".

Fungal pathogenicity genes have been identified by developing libraries of genes from specialized structures such as appressoria, screening for pertinent genes on the basis of highly expressed sequenced tags (ESTs), and a predicted ability of the protein product to exit the cell (SignalP) (2). Additionally, information on induction of defense responses has been derived by screening the eliciting ability of large numbers of chemical compounds with previously defined biological functions $(5,17)$.

In the model nonhost interaction between the bean pathogen $F$. solani $\mathrm{f}$. sp. phaseoli and pea endocarp tissue, the intact macroconidia of the bean pathogen, applied to the pea tissue in advance of the pea pathogen, generates a nonhost resistance response that terminates the growth of the pea pathogen. Conversely, the pea pathogen applied to bean tissue in advance of a bean pathogen renders the bean tissue resistant to the bean pathogen. 
There are two known biotic elicitors, chitosan and $F$. solani f. sp. phaseoli DNase, that trigger the nonhost resistance in the pea tissue (12). Each of these elicitors released by the fungus is capable of activating the complete resistance response in pea tissue to the true pea pathogen $F$. solani f. sp. pisi. Multiple genes are involved with the biosynthesis of chitosan in the fungus. Thus, the analyses and transgenic manipulations for elicitation of the defense response using DNase genes is simpler because only a single open reading frame (ORF) is involved. The use of single fungal DNase genes provides a simpler route for transferring resistance to a recipient plant via genetic engineering (6).

Nonhost resistance, by definition, is a property of the plant that enables it to resist most of the microorganisms in its environment, including both saprophytic fungi and the fungal pathogens virulent on other specific hosts. In nature, this resistance supports a common principle long recognized by pathologists that "susceptibility is the exception rather than the rule". Complete molecular explanations for how or why this occurs have not been forthcoming. This report draws attention to the accumulating evidence that fungal DNases exist in both plant-pathogenic fungi and many other fungi in the environment. Additional specialized functions are likely to be required for pathogenicity per se, such as those for external actions against barriers (e.g., cuticle, cell wall, or membrane) or mechanisms required for adhesion, penetration, and subsequent influences on host metabolism (12) as well as the functions that elicit or suppress host defense responses (21). However, an examination of both the catalytic function and occurrence of fungal DNases that are potentially capable of inducing defense responses in plants is the focus of this report. Though the homology of the predicted amino acid sequence of the protein product of the mitochondrial DNase gene in the yeast (Saccharomyces cerevisiae) fungus is somewhat distant from that of the DNase genes in some plant-pathogenic fungi, its catalytic activity is similar. Thus, this saprophytic fungus was selected as an inappropriate fungus to demonstrate that the catalytic DNase activity it releases is also capable of inducing the nonhost defense response.

In the pea endocarp model $(12,13)$ for assaying nonhost resistance responses, the challenging pathogen interfaces with a cuticle-less plant tissue. When challenged by $F$. solani $\mathrm{f}$. sp. phaseoli, DNA damage within the nuclei in the upper cells of this plant endocarp tissue occurs within the first hour postinoculation (14). That this DNA single-strand nicking action can be attributed to the presence of the pathogen has been verified by TUNEL assays (19) and by the direct measure of DNase catalytic activity within the isolated pea nuclei (11). Additionally, the induction of multiple pathogenesis-related (PR) genes evaluated via Northern analyses is evident in the postinoculation period. PR genes are typically induced starting within 1 to $2 \mathrm{~h}$ of the DNase treatment (19). Complete resistance to an inappropriate pathogen occurs within $6 \mathrm{~h}$ pi. The hypersensitive response, pisatin accumulation, and cell death occur within 6 to $24 \mathrm{~h}$ (5). Therefore, we consider the DNase protein to be a major, early signal in initiating the defense response. Because nonhost resistance responses of pea are activated by all of the inappropriate fungal pathogens tested to date, it is useful to examine homologies within these various types of DNases and evaluate their potential for release from the fungal cell. The universality of both the TatD-type DNases (27) and mitochondrial DNases are addressed. The TatD homologies refer to those previously described for DNases from other organisms that are primarily localized in the cytoplasm whereas many of the mitochondrial DNases are secreted or possess the potential for secretion.

Theory and approach. The theory being addressed is as follows: DNases have the potential to induce a disease resistance response that develops stable resistance in pea tissue, and those predicted to be released from many genera of fungal pathogens are predicted to play a major role in inducing nonhost resistance responses in multiple host-fungus interactions.

\section{MATERIALS AND METHODS}

Biological and sequence sources. DNase sequence data were obtained starting from sequences identified by the Broad Institute Verticillium group Database. Also, primers were developed from conservative regions of many TatD-like DNases listed in GenBank. With the availability of the total sequencing of $V$. dahliae and $V$. albo-atrum, additional information was found in "predicted" DNases which had some homology with the DNase1 from $F$. solani f. sp. phaseoli ( $F$. solani f. sp. phaseoli DNase) cloned previously $(15,19)$. BLAST analyses starting with the Fusarium or Verticillium DNase sequences revealed amino acid sequence homologies in a wide array of fungi that have previously been sequenced. For example, DNase genes were identified from $V$. dahliae by the Broad Institute's Verticillium Working Group that included the mitochondrial DNase gene with the accession number VDAG_06446.1. This accession number was used to obtain the translated protein sequence that was, in turn, the sequence entered into the NBCI BLAST program. The SignalP designations were derived using the SignalP 3.0 server (2) that proclaims the objective of "improved prediction of signal peptides" and was used in preference to the SignalP 4.0 server with the stated objective of "improved discrimination between signal peptides and trans-membrane regions". Other online programs such as InterProScan and CDART provided conformational data on functional domains of homologous sequences identified in the BLAST. Of those with somewhat distant homologies, the saprophyte $S$. cerevisiae (yeast) was selected to demonstrate the potential for this source of DNase to activate the defense response monitored by production of pisatin, PR gene induction, and cytologically detectable growth suppression of a pea pathogen on pea tissue. A proprietary, unidentified strain of $S$. cerevisiae was utilized because of the abundance and consistency of starting material from a commercial yeast product, Red Star baker's yeast, marketed by Lesaffre Yeast Corporation, Milwaukee, WI. A second source of yeast (red yeast) marketed for wine-making was from Fermentis Algist Bruggeman N. V., Langerbraggekaal, 9000 GENT, Belgium. Pure animal DNase1 enzymes from commercial suppliers (Worthington, EU-accession number P00639 and Fermentas, $\mathrm{NJ}$ ) were exploited in related experiments to induce resistance to $F$. solani f. sp. pisi in pea endocarp tissue for comparative purposes.

Partial purification of yeast DNase. Evaluations of the effector (elicitor) activity and general catalytic activities of yeast DNase and defense activation (pisatin induction and PR gene induction) used purified DNase released from yeast cell cultures grown in shake culture. The desiccated yeast cells were aseptically administered, $25 \mathrm{mg}$ dry weight to $50 \mathrm{ml}$ of Vogel's complete medium (23) without sucrose in 250-ml flasks. The shake cultures were harvested after 2 to 4 days and the 5,000-rpm supernatant of the pelleted cells was salt precipitated with $45 \%$ ammonium sulfate. The resulting supernatant was further precipitated with $80 \%$ ammonium sulfate to obtain the fraction with DNase activity. The $80 \%$ pellet was redissolved in buffer and dialyzed overnight against water. The salt-free enzyme was separated on a Superdex 75 (GE Healthcare Bio-Sciences Inc., Piscataway, NJ) column (10 by $260 \mathrm{~mm})$. Active fractions $(2 \mathrm{ml})$ were eluted with $0.1 \mathrm{~N} \mathrm{NaCl}$ and $0.1 \mathrm{mM}$ Tris buffer, $\mathrm{pH} 6.5$. DNase activity was identified in a reaction containing $3 \mu \mathrm{l}$ of eluate and $0.2 \mu \mathrm{g}$ of plasmid DNA in $2.5 \mu \mathrm{l}$ of $5 \mathrm{mM}$ MES buffer ( $\mathrm{pH}$ 6.1) containing $1 \mathrm{mM} \mathrm{MnCl}_{2}$. One unit of DNase was arbitrarily defined as that which can digest $0.2 \mu \mathrm{g}$ of plasmid DNA within $10 \mathrm{~min}$.

Quantification of pisatin. Peak activity fractions from the Superdex 75 separation of DNase from baker's yeast were 
dialyzed and $25 \mu \mathrm{l}$ was applied to the endocarp surface of the pea pod half $(0.2 \mathrm{~g}$ fresh weight $[\mathrm{FW}])$. Intact yeast cells were also applied to pea endocarp tissue and evaluated as potential elicitors of pisatin. Pisatin accumulation at $24 \mathrm{~h}$ was recovered with hexane extraction. The hexane residue was dissolved in $1.0 \mathrm{ml}$ of $95 \%$ ethanol and quantified at an optical density at $309 \mathrm{~nm}$ (17).

Reverse-transcription polymerase chain reaction monitoring of PR gene induction. DNase ( 1 to 2 units/ $\mu$ l) from baker's yeast purified as above, except through two Superdex 75 separations, was applied at $10 \mu \mathrm{l}$ per pea pod half $(0.28 \mathrm{~g} \mathrm{FW})$. This pea endocarp tissue was also treated with suspensions of intact yeast cells $\left(8 \times 10^{7}\right)$ and $F$. solani f. sp. phaseoli or $F$. solani f. sp. pisi spores $\left(4 \times 10^{6} / \mathrm{ml}\right)$. Pea tissue was frozen in liquid nitrogen 4 and $7 \mathrm{~h}$ after treatment. The tissue was ground in liquid nitrogen and solubilized in buffer number 1 (sodium perchlorate, $5 \mathrm{M}$; Tris base, $0.5 \mathrm{M}$; sodium dodecyl sulfate, $2.5 \% ; \mathrm{NaCl} 0.05 \%$; and disodium EGTA, $0.05 \mathrm{M})$. Following centrifugation $(5,000 \mathrm{rpm})$, the DNA and RNA were precipitated from the clear supernatant solution with 2.5 volumes of $95 \%$ ethanol. The nucleic acids were redissolved in water and chloroform or phenol extracted; total nucleic acids were reprecipitated from the aqueous phase with three volumes of $95 \%$ ethanol and redissolved in water. This water phase was adjusted to $2.0 \mathrm{M}$ lithium chloride to precipitate the RNA. The total RNA from each sample was pelleted at $15,000 \times g$ for $15 \mathrm{~min}$. The pellets were washed with cold $70 \%$ ethanol and air dried. Each dried RNA pellet was resuspended in $89 \mu \mathrm{l}$ of distilled $(\mathrm{d}) \mathrm{H}_{2} \mathrm{O}$ and treated with RNAse-free DNase 1 (Sigma-Aldrich, St. Louis) for $30 \mathrm{~min}$ at $37^{\circ} \mathrm{C}$. DNase-treated samples were chloroform extracted and reprecipitated with $1 / 10$ volume of $3 \mathrm{M} \mathrm{NaOAc}$ and 2 volumes of $100 \%$ ethanol. The RNA pellets were resuspended in $100 \mu \mathrm{l}$ of sterile $\mathrm{dH}_{2} \mathrm{O}$ and quantified with ND-1000 NanoDrop Spectrophotometer (NanoDrop Products, Wilmington, DE). The cDNA was synthesized using $100 \mathrm{ng}$ of RNA per reaction and the Superscript VILO cDNA Synthesis kit (Invitrogen) according to the manufacturer's protocol.

The genes targeted for real-time polymerase chain reaction (PCR) are listed in Table 1. The primers were designed using the sequences posted in GenBank for each gene and using Primer Express 3.0 (Applied Biosystems, Foster City, CA). All primers used are listed in Table 1. Real-time PCR reactions were set up using the Power SYBR Green PCR Master Mix (Applied Biosystems) according to manufacturer's directions and run on an Applied Biosystems 7500 real-time PCR machine. Thermocycling conditions were $50^{\circ} \mathrm{C}$ for $2 \mathrm{~min}$ and $95^{\circ} \mathrm{C}$ for $10 \mathrm{~min}$, followed by 40 cycles at $95^{\circ} \mathrm{C}$ for $15 \mathrm{~s}$ and $60^{\circ} \mathrm{C}$ for $1 \mathrm{~min}$, with melt curve set at $95^{\circ} \mathrm{C}$ for $15 \mathrm{~s}, 60^{\circ} \mathrm{C}$ for $1 \mathrm{~min}, 95^{\circ} \mathrm{C}$ for $30 \mathrm{~s}$, and $60^{\circ} \mathrm{C}$ for $15 \mathrm{~s}$. Assays were normalized using expression of both the pea actin gene and the pea ubiquitin gene. There were three replicates of each sample at each time point and each experiment. Relative expression levels were calculated by the $\Delta \Delta \mathrm{CT}$ method using the QbasePLUS version 2.3 software package (Biogazelle, Zwijnaarde, Belgium).

Cytology of DNase-induced resistance based on the growth of $\boldsymbol{F}$. solani f. sp. pisi conidia on pea. A dilution series of yeast DNase enzyme activity starting with 80 units was applied in $25-\mu 1$ volumes to the endocarp surface of pea pod halves followed in 30 min with a $10-\mu$ l overlay of $F$. solani $\mathrm{f}$. sp. pisi spores $(1 \times$ $10^{7}$ spores/ml). At $24-\mathrm{h}$ intervals postinoculation, razor-blade sections of the inoculated endocarp surface were treated with cotton blue and the growth of the macroconidial spores recorded (25 observations/section). Hyphal growth was measured in terms of the macroconidial spore lengths $(45 \mathrm{~nm})$ and photographed in a light microscope. Also, the presence of the yellow-green hypersensitivity accumulation in pea tissue surrounding the fungal spore, typically associated with nonhost resistance, was recorded. In corollary experiments, a dilution series of the commercial, pure calf thymus DNase was employed (0.15 to 10 units, defined by the Fermentis company) similarly to reassess the general action of nuclease in both suppressing and inducing plant defense against $F$. solani f. sp. pisi. All cytological assays of the defense response were repeated three times with separate harvests of pea pods.

Assay of the direct antifungal effect of DNase on $F$. solani $f$. sp. pisi. An enzyme unit dilution series starting with $50 \mu \mathrm{l}$ $(\approx 160$ units) of the peak yeast DNase activity fraction from the Superdex 75 separation was half-fold diluted against complete Vogel's medium, followed by the addition of $5 \mu \mathrm{l}$ of the $F$. solani f. sp. pisi fungal spore suspension in each of the micro-dilution plate wells. Growth was recorded at 24 and $48 \mathrm{~h}$. Similar series were engaged against $F$. solani $\mathrm{f}$. sp. pisi with commercial, pure DNase1 (produced in expression vectors using animal genes).

In vivo quantitation of pea nuclear DNA damage and nuclei distortion. The endocarp surfaces of pod halves were treated with $20 \mu \mathrm{l}$ of water and yeast DNase $(1 \mathrm{unit} / \mu \mathrm{l})$ of baker's (or winemaking) yeast cells at $5 \mathrm{mg} / \mathrm{ml}$ for 4 to $5 \mathrm{~h}$. The treatments were removed with $10-\mathrm{ml}$ washes of sterile water. Total DNA was extracted as described (17). Aliquots $(90 \mu \mathrm{g})$ of DNA (2 ml) were encumbered in $1 \%$ molten CHEF-gel grade agarose in alkaline buffer (30 mM NaOH and $4 \mathrm{mM}$ EDTA) and solidified in a 4-cmdiameter well. The gel was topped with $3 \mathrm{ml}$ of alkaline buffer and the single-stranded DNA was allowed to diffuse out over $48 \mathrm{~h}$ with rotation. DNA was precipitated with three volumes of ethanol and was subsequently separated electrophoretically on $1 \%$ agarose gel (containing ethidium bromide). Epidermis sections of similarly treated pod halves were stained with 4',6-diamidino-2phenyliadole (DAPI) $(1 \mathrm{mg} / \mathrm{ml})$ and viewed at high power in an Olympus UV microscope. Uniform microscope fields were photographed and printed and the sizes of 40 nuclei per treatment measured directly in millimeters.

\section{RESULTS AND DISCUSSION}

A major research objective was to indicate both the actual or predicted presence and the relative homologies of DNases within the fungal genome sequences available to date. Second, the sequence data were used to determine whether the $\mathrm{N}$-terminal end of each predicted protein product possessed the potential to be secreted. Although cross referencing the DNA sequences was useful, the most meaningful analyses of homology occurred when BLAST searches were conducted with protein-to-protein searches. The data in Table 2 indicate the presence of amino acid sequence homologies among mitochondrial nucleases over a wide range of fungal genera.

The Broad Institute Verticillium working group and others have discovered putative sequences that are homologous with fungal mitochondrial DNases. A NCBI BLAST search detected many known fungal DNase sequences, including those within the

TABLE 1. Targets used for real-time quantitative polymerase chain reaction, GenBank accession numbers, and primer sequences

\begin{tabular}{|c|c|c|c|}
\hline Target & GenBank number & Real-time F primer & Real-time $\mathrm{R}$ primer \\
\hline Pea ubiquitin & L881142 & GGCTAAGATACAGGACAAGGAG & AACGAAGGACAAGATGAAGGG \\
\hline Pea actin (Pea-ACT) & U81046 & CACAATTGGCGCTGAAAGATT & GATCATCGATGGCTGGAACA \\
\hline DRR206 & U11716 & CTTGGCTTAGTTTCACATTTGTTCTT & GGGTCAGCTCCAGCAAAAGTAA \\
\hline DRR230 (defensin) & L01579 & TGTGGTGACAGAGGCAAACAC & TCGTGAAGCATACTCCCCTGTA \\
\hline PR10 (AKA DRR49) & U31669 & GATCTCATTCGAGGCTAAACTGTCT & CACACTCAGCTTTGCAATGGA \\
\hline PR1b & AJ586324.1 & AACTCATGTGCTGCTGGTTATCA & AACCGAATTGCGCCAAAC \\
\hline
\end{tabular}


genomes of some major fungal plant pathogens (Table 2). The resultant nuclease homologies extended through to fungi that are often considered saprophytes or household contaminants. Information on mitochondrial nuclease alignment homologies is included in Figure 1. Interestingly, the DNase homologies also link those of plant pathogens to fungal DNases associated with human, insect, and other animal specificities. This homology raises the possibility that these DNases also possess the ability to elicit defensive actions within many other living non-plant tissues. For example, the protein coded by accession ACT37324.1 (Table 3 ) has a stated nuclease function and is also functional as a human antigen.

The evolutionary conservation by fungi of genes for secreted DNases may have resulted from the ability of these enzyme proteins to derive nutrition via the digestion of nucleic acids in the organic residues within its environment. DNases may be beneficial to fungi in confronting DNA secretions from root tips (26). The effectiveness by which the $F$. solani f. sp. phaseoli DNase from the bean pathogen, $F$. solani f. sp. phaseoli, is able, at very low protein levels (15), to induce defense responses in pea tissue may suggest that this enzyme was also evolutionarily retained for interacting with other live biological entities. Although certain low-level DNase releases induce "self-defeating" defense responses against the fungus, higher DNase levels are eventually capable of killing plant cells (15).
The closest amino acid sequence homology existed between the DNase1 of $F$. solani $\mathrm{f}$. sp. phaseoli, a bean pathogen, and that of a closely related $F$. solani f. sp. pisi (annot. N. haematococca) (Table 3). This comparison was made possible by the availability of the complete sequence of this pea pathogen (7). Interestingly, the N-terminal sequence of the N. haematococca locus AF17291, listed as a putative DNase, scores negatively in the SignalP analysis. However, this locus may code a smaller protein by starting at a secondary transcriptional start site that does contain a code for a positive SignalP designation. Accession XP_003050462 from $N$. haematococca also contains a predicted DNase function and possesses a potential SignalP-positive N-terminal sequence. The two start sites, one with and one without the N-terminal signal sequence, have been reported previously (12). The accessions that were predicted to be without a signal sequence and nonsecretory were likewise predicted to be nonsecretory using FunSecKB, the fungal secretome knowledgebase program (20). The close amino acid sequence alignments (Fig. 1) of accessions presented in Tables 2 and 3 (not shown) suggest that unnamed proteins, with homology scores ranking among those with predicted DNase functions, would also have a high probability for coding DNase functions. The sequence information from these proteins is currently functionally designated as "unknowns" or "hypothetical proteins". This comparative information provides routes of access via their nucleotide ORF sequences for devel-

TABLE 2. Amino acid sequence homology of Verticillium dahliae mitochondrial DNase protein, VDAG_06446.1, compared with that of other fungi ${ }^{\mathrm{a}}$

\begin{tabular}{|c|c|c|c|c|}
\hline Accession & Function & Binomial & Occurrence & Score, Sig \\
\hline VDAG_06446.1 & Nuclease & Verticillium dahliae & Plants $(n \approx 300)$, potato & $602+$ \\
\hline XP_00300992.1 & Nuclease & V. albo-atrum & Plants, alfalfa & $602+$ \\
\hline EFQ28514.1 & Nuclease & Glomerella graminicola & Cotton, cereals & $512+$ \\
\hline XP_957017.1 & Nuclease & Neurospora crassa & Bread mold & $467+$ \\
\hline EFȲ9744.1 & Nuclease & Metarhizium anisopliae & Insects & $460+$ \\
\hline EFY86777.1 & Nuclease & M. acridum & Grasshopper & $460+$ \\
\hline CB151937.1 & Unknown & Sordaria macrospora & Saprophyte, genetic & $454+$ \\
\hline XP_359453.2 & Protein & Magnaporthe oryzae & Rice blast & $459+$ \\
\hline XP_003052342.1 & Unknown & Nectria haematoccoa & Pea root rot & $452+$ \\
\hline XP_386862.1 & Protein & Gibberella zeae & Wheat head blight & $451-$ \\
\hline XP_001551161.1 & Protein & Botyrotinia fuckeliana & Gray mold grapes & $444+$ \\
\hline XP_001585330.1 & Protein & Sclerotinia sclerotiorum & White mold, plants & $436-$ \\
\hline XP_001221836.1 & Protein & Chaetomium globosum & Soil, peritonitis & $436+$ \\
\hline EFX00164.1 & Nuclease & Grosmannia clavigera & Blue stain, pine & $433+$ \\
\hline ADR82277.1 & Nuclease & Blumeria graminis-tritici & Wheat, powdery mildew & $419+$ \\
\hline XP_001908324.1 & Protein & Podospora anserina & Genetic model & $410-$ \\
\hline XP_001806540.1 & Protein & Phaeophaeria nodorum & Wheat glume blotch & $409+$ \\
\hline EFQ̄85279.1 & Protein & Pyrenophora teres f. teres & Barley net blotch & $408+$ \\
\hline XP_001941137.1 & Protein & Pyrenophora tritici & Wheat tan spot & $407+$ \\
\hline СВХ̄ 9742.1 & Protein & Leptosphaeria maculans & Brassica black leg & $405+$ \\
\hline XP_002789019.1 & Nuclease & Paracoccidiodes brasiliense & Lungs, mouth, nose & $401+$ \\
\hline $\mathrm{EE} \overline{\mathrm{H}} 49242.1$ & Nuclease & Paracoccidiodes brasiliense & Lungs, mouth, nose & $401+$ \\
\hline XP_002541269.1 & Nuclease & Uncinocarpus reesii & Human, nonpathogenic & $400+$ \\
\hline EER 45824.1 & Nuclease & Ajellomyces capsulatus & Darling's disease & $399+$ \\
\hline XP_003066263.1 & Precursor & Coccidioides posadasil & Valley fever-soil & $399+$ \\
\hline AAK62983.1 & Nuclease & C. immitis & Valley fever-soil & $398+$ \\
\hline ЕEH07668 & Nuclease & Ajellomyces capsulatis & Darling's disease & $397+$ \\
\hline XP_755209.1 & Nuclease & Aspergillus fumagatus & Organic matter & $392+$ \\
\hline XP_003018855.1 & Protein & Trichophyton verrucosum & Cattle, ringworm & $391+$ \\
\hline XP_002621450.1 & Nuclease & Ajellomyces dermatitidis & Blastomycosis & $390+$ \\
\hline XP_003174618.1 & Protein & Arthroderma gypseum & Human keratin tissue & $390+$ \\
\hline XP_659789.1 & Nuclease & Aspergillus nidulans & Research organism & $389+$ \\
\hline XP_001260379.1 & Nuclease & Neosartorya fischeri & Bone marrow & $389+$ \\
\hline XP_002846750.1 & Nuclease & Arthroderma otae & Human, ringworm & $387+$ \\
\hline XP_002558817.1 & Unknown & Penicillium chrysogenum & Mold on food & $387+$ \\
\hline XP_003016646.1 & Protein & A. benhamiae & Tina corpis, human & $387+$ \\
\hline $\mathrm{EE} \overline{\mathrm{H}} 22485.1$ & Nuclease & Paracoccidiodes brasiliense & Mycosis & $386+$ \\
\hline EGD93560.1 & Nuclease & Tricophyton equinum & Tinea capitis, human & $386+$ \\
\hline EGD87157.1 & Nuclease & T. rubrum & Athletes foot & $385+$ \\
\hline XP_001267802.1 & Nuclease & Aspergillus clavatus & Soil, manure & $381+$ \\
\hline XP_00128339.1 & Nuclease & A. terreus & Commercial mold & $376+$ \\
\hline NP_00128339.1 & Nuclease & Saccharyomyces cerevisiae & Grape skin & $369+$ \\
\hline
\end{tabular}

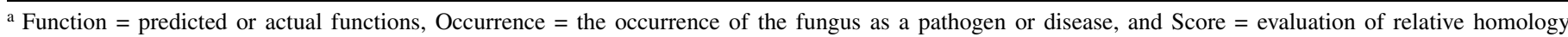
provided by the BLAST analysis. The potential of each to be secreted is indicated by a positive SignalP (Sig.) analysis. 


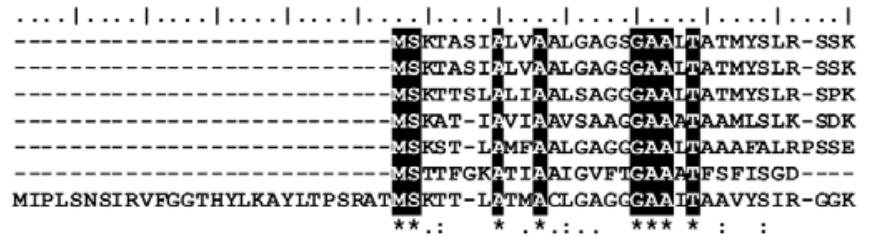

V.d.

v.a.

G.g.

N.c.

M.a.

M.o.

G. $z$.

ClustalW Consensus

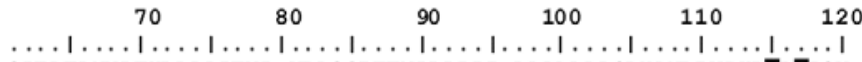
QPEATLNVPTHLAAAPTVP-VPASQIFTNPP PPPP-AAAAAAAGPHANLPVLKPVDPACW QFEATLHVPTHLAAAPTVP-VPASOI FTN PPP P PPP PP PAAAAGPHANLPVLKPVDPAGW QPAPSTTNASPPLNSPSVP-VPATQVFTNPSAPLP-PAAAAPSPPLPGSSGNPVDPAGL KVDTT-SLNAPVP------AAPSKPGPVPASQVESAPALAGGYKP------VDPSAF NKK PELPIATPPTARPNN---AASTTALAIP SQHVY ST SP PVS -GAP-------VNPAGL --KSTTPVLADIS--------SKPGESHKLPTPGNTGGHPVPS--TP-------VDPAGL RVEETNTLATPP PTTNSFAALPAPTASPS IPPTQVFGP PAGAPPS TPVDINAIVNPAGL

V.d.
V.a.
G.g.
N.c.
M.a.
M.o.
G.z.

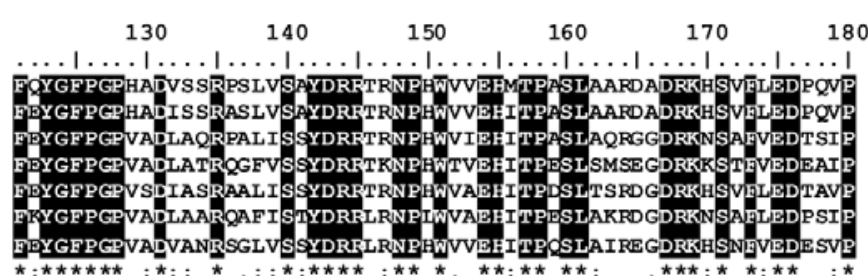

clustalw Consensus

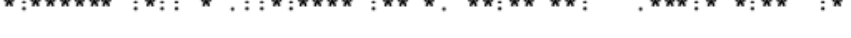

V.d.
V.a.
G.g.
N.c.
M.a.
M.o.
G. z.

ClustalW Consensus

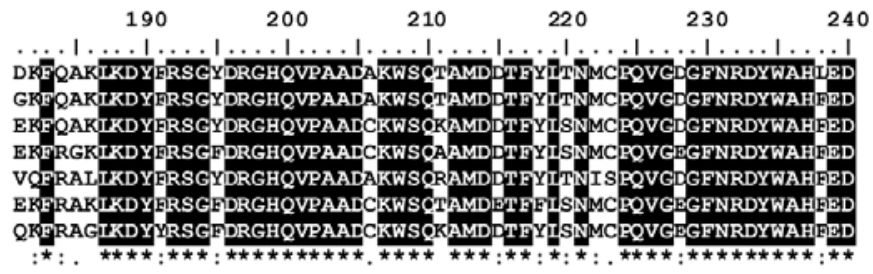

V.d.
V.a.
G.g.
N.c.
M.a.
M.o.
G.z.
Clustalw Consensus
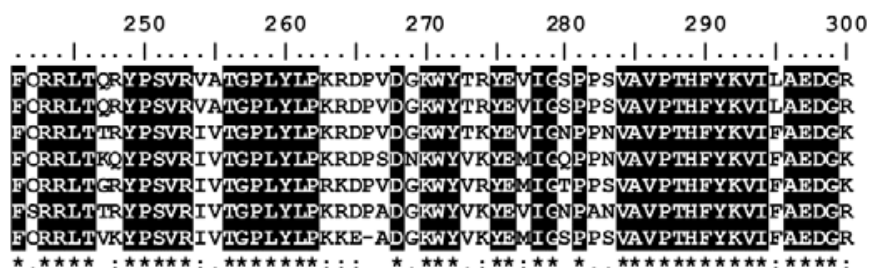

v.d.
v.a.
G.g.
N.c.
M.a.
M.o.
G. z.

Clustalw Consensus
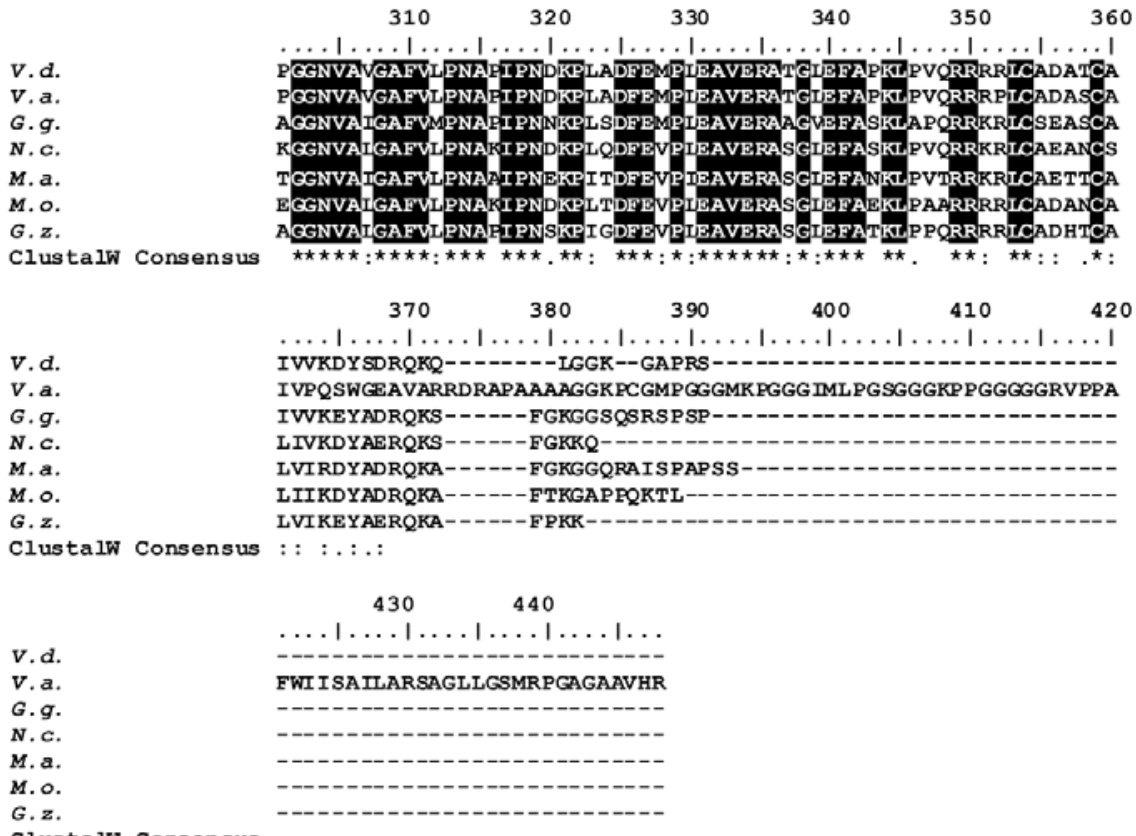

clustalw Consensus

Fig. 1. Close homology of selected amino acid sequence regions of fungal mitochondrial DNases of Table 1 is indicated by "ClustalW" alignments. Symbols: * = identical, : = conserved for charge and hydrophobicity, . = conserved for charge or hydrophobicity, black shading $=100 \%$ identical, V.d. $=$ Verticillium dahliae, V.a. = Verticillium albo-atrum, G.g. = Glomerella graminicola, N.c. = Neurospora crassa, M.a. = Metarhizium anisopliae, M.o. = Magnaporthe oryzae, and G.z. $=$ Gibberella zeae. 
oping expression vectors. Theoretically, the gene products released from suitable expression vectors could also be generated in quantities adequate for direct catalytic assays of their nuclease activities. However, DNase synthesis within an expression vector system designed for high-level enzyme production is fraught with the presence of excessive DNase and the potential for toxicity.

Other genes coding proteins with predicted DNase activity. The contribution of individual fungal genes by reductive mutagenesis will face the fact that fungi, like other organisms, contain multiple proteins with DNase activity. For example, in addition to the TatD DNase and mitochondrial DNase, other loci of Verticillium such as VDAG_08010.1 and VDAG_09866.1 of V. dahliae contain genes for the Cut9-interacting protein $\operatorname{sen} 1$ and a DNA-repair protein, respectively. Likewise, the VDBG_01252.1 and VDBG_03519.1 loci of V. albo-atrum contain the genes for a Cut9-interacting protein $\operatorname{scn} 1$ and DNA repair protein $\operatorname{rad} 2$, respectively. Puccinia graminis f. sp. tritici has two predicted TatD-like DNases genes, PGTG_16749.2 and PTTG_09333.2, both with signal peptides. $P$. triticina has two predicted DNaselike genes, PRRG_07594.1 and PGTG_02074.1; both are predicted to be nonsecretory.

DNase present in the saprophyte, yeast. The low DNase homology score for yeast (S. cereviseae) DNase of 369 (Table 2) compared with the 602 score of $V$. dahliae indicates its diversity from that of an authentic fungal plant pathogen. That both sequences are predicted to code related nucleases is based on the $63 \%$ "Max ident" value of an NCBI BLAST, directed between yeast and Verticillium DNases. Thus, the yeast was selected to determine whether the DNase from this distantly related fungus can, as a saprophyte, induce defense responses in pea. The biosynthesis of the phytoalexin, pisatin, is a reliable indicator of the defense response in pea tissue, because the activation of genes coding for secondary enzymes such as phenylalanine ammonialyase contribute to its induction (8). Also, the activation of several PR genes is consistently associated with these defense responses (15).

Secretion of $S$. cerevisiae DNase activity and pisatin induction. The DNase activity assay (Fig. 2) of the Superdex 75 separation enables the detection and recovery of the fractions eluted from yeast containing nuclease activity (lanes 3 to 5). The activity present in fraction number 5 (refractionated through the Superdex 75 column) was used to evaluate the pisatin-eliciting potential of yeast DNase (Fig. 3). In total, four units of yeast DNase is adequate to cause $1 \mathrm{~g}$ of pea pod tissue to accumulate 16 $\mu \mathrm{g}$ if pisatin within $24 \mathrm{~h}$ (Fig. 3). The pisatin induction was somewhat DNase-concentration dependent. The four units and higher levels of DNase induced pisatin, and less induction was observed with lower concentrations (two to four units) of the enzyme. All of these pisatin levels fall short of what is induced within $24 \mathrm{~h}$ following inoculation by the intact spores of $F$. solani f. sp. phaseoli (15) or yeast cells (Table 4). The higher intensity of induction by the intact spores is likely augmented by the release of low molecular weight elicitors $(16,22)$ which are lost in the purification of DNase. Also, a cell-controlled release could optimize the enzyme concentration and assist the direct release of nuclease into the plant cell, because the signal peptide is attached to the DNase protein in the intact yeast cell and is predicted to have been cleaved from the DNase when it has reached the

TABLE 3. DNase1-like fungal DNases listed in order of their homology scores derived from an amino acid sequence BLAST analysis using the accession, AAD5390.1, of Fusarium solani f. sp. phaseoli DNase ${ }^{\mathrm{a}}$

\begin{tabular}{|c|c|c|c|c|}
\hline Accession & Function & Binomial & Occurrence & Score, Sig. \\
\hline AAD53090.1 & DNase1 & Fusarium solani & Bean root rot & $567-1+$ \\
\hline AF17291-(locus) & DNase & Nectria haematococca & Pea root rot & $567-1+$ \\
\hline XP_003050462.1 & DNase1 & N. haematococca & Pea root rot & $309+$ \\
\hline CAB6306.1 & DNase1 & Metarhizium anisopliae & Insect fungus & $197+$ \\
\hline XP_386955 & Protein & Gibberella zeae & Wheathead blight & $195+$ \\
\hline EFY87986.1 & DNase1 & M. acridum & Grasshopper & $194+$ \\
\hline ACT37324.1 & Nuclease & Stachybotrys chartarum & Antigen, human & $167-$ \\
\hline EFQ27992.1 & DNase1 & Glomerella graminicola & Cotton, cereals & $160+$ \\
\hline XP_001558258.1 & Protein & Botryotinia fuckeliana & Grape mold & $137+$ \\
\hline XP_001911875.1 & Unnamed & Podospora anserina & Genetic model & $130+$ \\
\hline EFX02803.1 & DNase 1 & Grosmannia clavigera & Blue stain, pine & $130+$ \\
\hline XP_001591044.1 & Protein & Sclerotinia sclerotorium & White mold & $127+$ \\
\hline XP_363060.1 & Protein & Magnaporthe oryzae & Rice blast & $115+$ \\
\hline CBI54481.1 & Unnamed & Sordaria macrospora & Genetic model & $92.8+$ \\
\hline XP_961539.1 & Protein & Neurospora crassa & Bread mold & $83.6+$ \\
\hline XP_001549366.1 & Protein & Botryotiania fuckelianna & Grape mold & $72.0+$ \\
\hline XP_001551751.1 & Protein & B. fuckelianna & Grape mold & $65.1+$ \\
\hline XP_001594139.1 & Protein & Sclerotinia sclerotiorum & Plant species & $61.6+$ \\
\hline XP_00158466.1 & Protein & S. sclerotiorum & Plant species & $57.0+$ \\
\hline
\end{tabular}

${ }^{a}$ Presence (+) or absence (-) of the SignalP 3.0 server prediction of an N-terminal signal sequence (Sig.) is indicated.

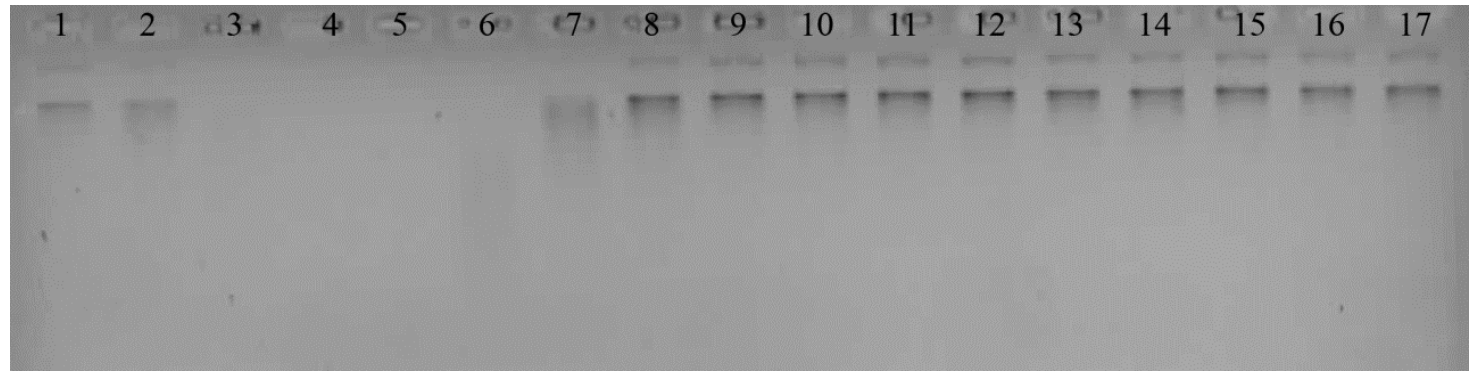

Fig. 2. Assay of DNase activity excreted from yeast cells within 2 days into Vogel's medium. Following a 40 to $85 \%$ ammonium sulfate fractionation of the medium, the dialyzed protein was condensed and fractionated on a Superdex 75 column. A 10-min reaction (see Materials and Methods) of $3 \mu l$ of fractions 1 to 16 ( lanes 1 to 16 ) were incubated for $10 \mathrm{~min}$ with $0.2 \mu \mathrm{g}$ if plasmid DNA. Lane $17=$ buffer control. Fraction number 5 was dialyzed and used for subsequent experiments. 
culture medium. The data indicate that the release of yeast DNase would be a factor in contact between yeast and pea tissue even though this contact may occur infrequently in nature and be unlikely to apply selective pressure in evolution. Further, because of the higher intensity elicitation of pisatin observed with the intact cells, it relegates the DNase elicitation alone to be an important but not the sole yeast component able to induce the defense response.

Pea PR gene induction by yeast DNase. The variable effects of two levels of yeast DNase on the early induction of pea PR genes provide another view of the defense response of pea endocarp tissue (Fig. 4). The pea gene products (targets listed in Table 1) include DRR206, a putative enzyme in lignin production (6); DRR230, a defensin (4); DRR49 (PR 10), a putative RNase (10); and PR1b, a putative PR1 gene product. The four-unit yeast DNase treatment effectively induced DRR49 and PR1b within $7 \mathrm{~h}$; however, four DNase units were not effective in inducing DRR206 and DRR230. The responses induced by four units of yeast DNase were partially mimicked by the intact yeast cell suspension treatment. The general inclusive induction by the two pathogenic fungi indicated a more complete defense response when compared with the saprophytic yeast or its purified DNase. The pea DRR49, when used individually, has a demonstrated ability to generate resistance transgenically (3). The meager or suppressed response of the DRR206 and DRR230 genes may indicate that the DNase action on some regions of the pea cellular DNA could experience temporally negative effects.

Catalytic action of yeast DNase on pea DNA in vivo. The effect of the addition of either intact yeast cells or the purified yeast DNase to pea tissue on internal pea DNA is shown in Figure 5 . Both the release of DNase from yeast cells and the application of purified DNase directly to the pea tissue have the potential to cleave nuclear DNA. It was previously shown that levels of DNase adequate to induce defense responses cause only subtle changes in the host cell DNA (19). Thus, to monitor the catalytic effects, both the bulk of the high molecular weight DNA must be

\begin{tabular}{lcccc} 
& \multicolumn{3}{c}{ YEAST NUCLEASE } & \\
UNITS & 4 & 2 & 1 & 0 \\
PISATIN & 15 & 20 & 0 & 0
\end{tabular}

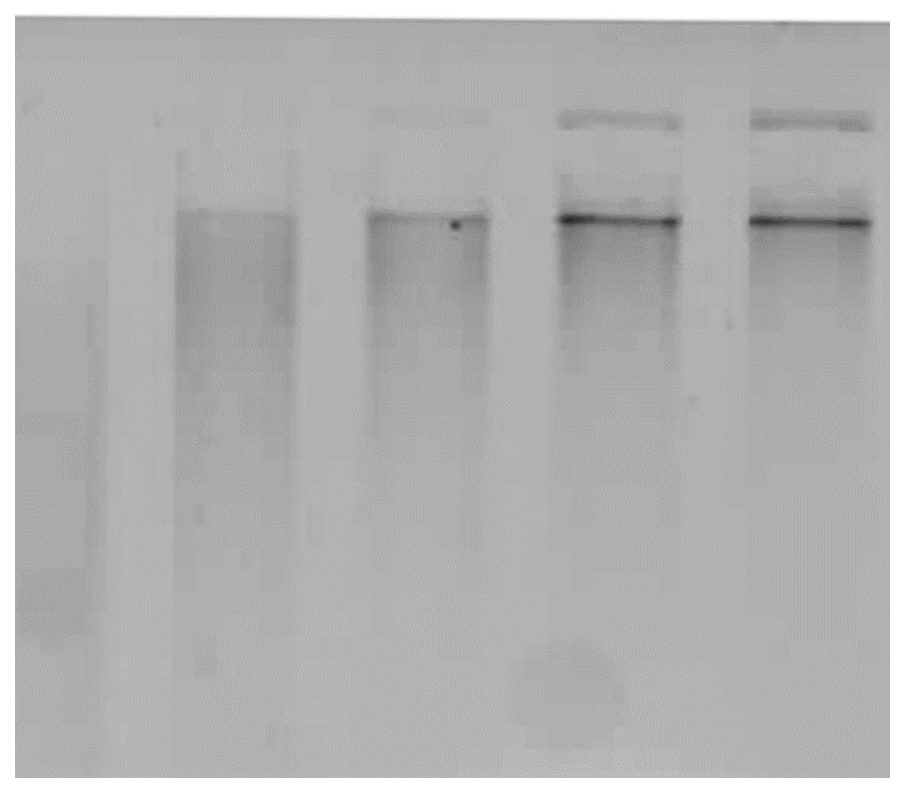

Fig. 3. Elicitation of 15 and $20 \mu \mathrm{g}$ of pisatin per gram of endocarp tissue, $24 \mathrm{~h}$ following the application of four and two units of yeast nuclease activity (10- $\mu 1$ volume from fraction 5; see Figure 3 ), respectively, to $0.3 \mathrm{~g}$ of pea pod. Gel separation shows the digestion of $0.2 \mu \mathrm{g}$ of plasmid DNA by $3 \mu$ of fraction 5 within $10 \mathrm{~min}$. The experiment was repeated twice with similar results. encumbered and the cleaved single strand must be allowed to separated in an alkaline buffer to detect released strands free of the bulk concentrations of intact pea genomic DNA. The DNA observed in Figure 5 consisted of cleaved strands that diffuse from of the total DNA trapped in agarose disks. The low levels of this DNA from either tissue treated with the yeast cells or the purified yeast DNase exceeded that from the water-treated control tissue, suggesting that some DNA digestion occurred within the pea cells in the treated tissue but much less digestion occurred in the control.

Assays of the direct inhibition of the in vitro growth of $F$. solani f. sp. pisi (Table 5) indicated that only the higher concentrations of 10 to 160 units per $50 \mu$ caused inhibited growth. This might indicate that relatively high DNase units also suppressed growth in the in vivo tests on the pod tissue.

S. cerevisiae nuclease induction of cytologically detectable resistance in pea. The in vivo growth of $F$. solani $\mathrm{f}$. sp. pisi was

TABLE 4. Pisatin accumulation induced in pea endocarp tissue by yeast cells

\begin{tabular}{lcc}
\hline $\begin{array}{l}\text { Treatment } \\
(\text { spores/ml) }\end{array}$ & $\begin{array}{c}\text { Pisatin } \\
(\mu \mathrm{g} / \mathrm{g} \text { fresh weight })^{\mathrm{b}}\end{array}$ & $\begin{array}{c}\text { Hypersensitive } \\
\text { response }^{\mathrm{c}}\end{array}$ \\
\hline 0 & 0.0 & 0 \\
$8 \times 10^{8}$ & $118.0 \pm 2.5$ & + \\
$8 \times 10^{7}$ & $54.6 \pm 4.0$ & + \\
$4 \times 10^{7}$ & $78.4 \pm 4.7$ & + \\
$2 \times 10^{7}$ & $28.9 \pm 4.9$ & + \\
$1 \times 10^{7}$ & $23.2 \pm 4.1$ & $\mathrm{~L}$ \\
$5 \times 10^{6}$ & $9.3 \pm 2.3$ & $\mathrm{~L}$ \\
$2.5 \times 10^{6}$ & $6.4 \pm 0.2$ & $\mathrm{~L}$ \\
$1.25 \times 10^{6}$ & $9.3 \pm 0.3$ & + \\
$6 \times 10^{5}$ & 0.0 & $\mathrm{VL}$ \\
$3 \times 10^{5}$ & 0.0 & 0 \\
$1.5 \times 10^{5}$ & 0.0 & 0 \\
\hline
\end{tabular}

${ }^{a}$ Pea pod endocarp tissue was treated with $20 \mu$ of water or the indicated cell count suspended in water.

b Pisatin was hexane extracted $24 \mathrm{~h}$ after treatment and its accumulation was assayed at an optical density at $309 \mathrm{~nm}$.

${ }^{c}$ Hypersensitive discoloration at $24 \mathrm{~h}$ : $0=$ none, $+=$ detectable, $\mathrm{L}=$ light, and $\mathrm{VL}=$ very light.

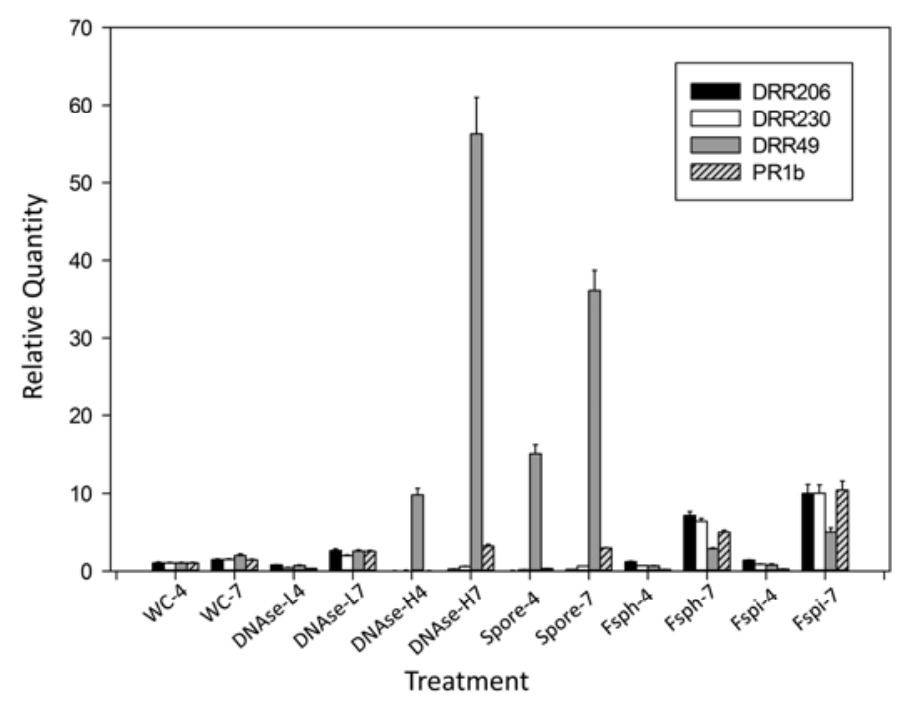

Fig. 4. Quantitative reverse-transcription polymerase chain reaction (qRTPCR) monitoring of the response of four pea pathogenesis-related genes (DRR206, DRR230, DRR49, and PR1b) following treatment of pea endocarp tissue with water, $4 \mathrm{~h}$ (WC-4) and $7 \mathrm{~h}$ (WC-7); yeast DNase, 2 units/ $\mu \mathrm{l}, 4 \mathrm{~h}$ (DNAase-L4) and $7 \mathrm{~h}$ (DNAse-L7); yeast DNase, 4 units/ $\mu \mathrm{l}, 4 \mathrm{~h}$ (DNAse-H4) and $7 \mathrm{~h}$ (DNAse-H7); $8 \times 10^{7}$ yeast cells, $4 \mathrm{~h}$ (Spore-4) and $7 \mathrm{~h}$ (Spore-7); F. solani f. sp. phaseoli at $4 \times 10^{6}$ spores/ml, $4 \mathrm{~h}($ Fsph-4) and $7 \mathrm{~h}$ (Fsph-7): F. solani f. sp. pisi at $4 \times 10^{6}$ spores/ml, $4 \mathrm{~h}$ ( Fspi-4) and $7 \mathrm{~h}$ (Fspi-7). Error bars indicate the standard error of the means. All qRT-PCR reactions were repeated twice with similar results. 
also completely suppressed in the interaction with pea endocarp tissue receiving pretreatment with levels of DNase below 10 units (Fig. 6B) at the 48-h point postinoculation, when the watertreated tissue (Fig. 6A) allowed F. solani f. sp. pisi growth extending beyond the microscopic field of view. When the DNase units are reduced to four units, growth up to three to four times the length of the $F$. solani f. sp. pisi spore occurred occasionally prior to distortion of the mycelia and complete suppression of growth (Fig. 6C). Thus, the suppression of F. solani f. sp. pisi growth on the endocarp surface, when below the concentrations that directly inhibited $F$. solani $\mathrm{f}$. sp. pisi growth in liquid culture, apparently resulted from the induced defense response of the pea tissue.

As indicated above, the intensity of the pisatin accumulation was dependent on the cell density of the yeast (Table 4) and, correspondingly, $5 \mu \mathrm{l}$ of intact yeast cells at $4.2 \times 10^{6} / \mathrm{ml}$ also had the potential to induce the defense response in pea against $F$. solani f. sp. pisi (Fig. 6E).

The individual contribution of DNase enzyme activity to the suppressed growth of $F$. solani $\mathrm{f}$. sp. pisi can also be demonstrated with the use of purified commercial enzymes from an animal

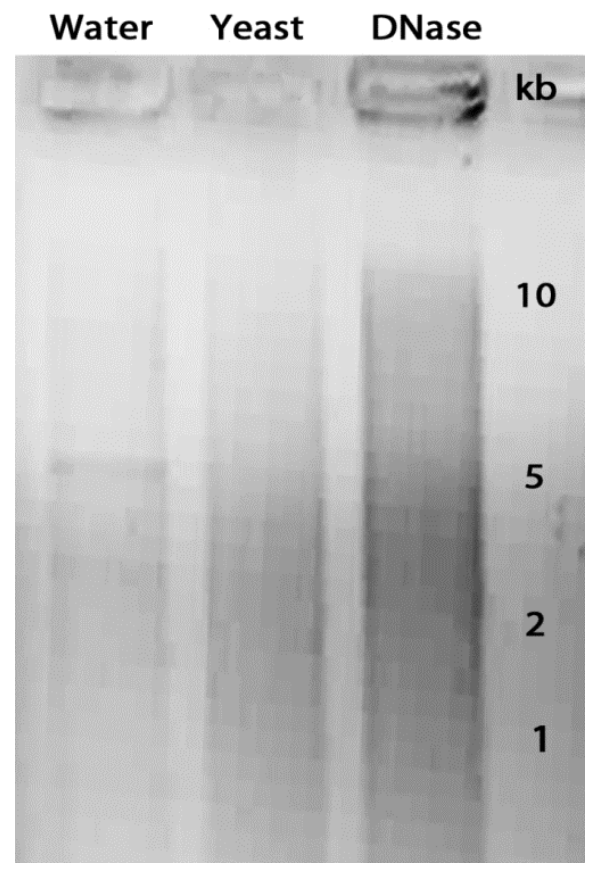

Fig. 5. Detection of pea low molecular weight DNA strands released from the total DNA (see Materials and Methods) extraction of $3 \mathrm{~g}$ of pea pods $5 \mathrm{~h}$ after treatment ( $10 \mu \mathrm{l}$ per pod half) with Lane $1, \mathrm{H}_{2} \mathrm{O}$ (Water); lane $2,8 \times 10^{7}$ yeast cells (Yeast); and lane 3, 10 units of yeast DNase (DNase). The experiment was repeated twice with similar results. source. F. solani $\mathrm{f}$. sp. pisi growth on the endocarp surface was suppressed with 0.6 units (Fermentas) of DNase (Fig. 6F) applied prior to inoculation with $F$. solani $\mathrm{f}$. sp. pisi spores. Five units of calf thymus DNase1 were adequate to cause pisatin accumulations of $20 \mu \mathrm{g} / \mathrm{g}$ of pea pod tissue within $24 \mathrm{~h}$. The signal sequence of this DNase1 protein has been cleaved off in the commercial preparation of the enzyme and, thus, is not available for transiting cell membranes.

Cytologically detectable changes in pea nuclei. Alterations in pea nuclei caused by either treatment with yeast cells or purified yeast DNase are subtle but detectable with DAPI staining. The staining intensity of the majority of the cells treated with yeast components is suppressed (Fig. 7). Also, the nuclei margins become less sharp and the nuclei increase in diameter $0.5 \%$ within $4.5 \mathrm{~h}$ when treated with $8 \times 10^{7}$ yeast cells, $1.15 \%$ with the purified yeast DNase 10 units per pod half, and $1.12 \%$ with yeast DNase at 1 unit per pod half.

Conclusions. This research evaluated the DNase from a saprophytic yeast as an elicitor of the pea defense response. These data, along with the homologies of the DNases from an array of fungi, suggest that the release of DNase activity is likely to be a factor in most fungus-plant interactions. Such releases are also predicted to occur as fungi interact with animals, insects, and so on.

There are many compounds and factors that can induce plant responses in nature $(5,17)$; however, the indicated fungi possess single genes that may directly code a DNase product capable of inducing the plant's defense response. Genetic engineering manipulations may, in the future, enable these genes to be transferred to plants and directly activate the defense response (6), as has been demonstrated with the $F$. solani $\mathrm{f}$. sp. phaseoli DNase gene. Thus, there is a nearly unlimited supply of DNase genes from fungal mitochondria to call upon. If the DNase genes from saprophytes are expressed at a lower level or are weaker catalysts than those from pathogenic fungi, there may be an advantage for their use as well. The gene coding the DNase from $F$. solani $\mathrm{f}$. sp. phaseoli, when transferred to potato, expressed resistance that was followed by the onset of senescence (6). The same gene construct successfully developed resistance without senescence when transferred to tobacco, indicating that a window of benefit lies between DNase action as an elicitor and DNase as implementer of cell death within each recipient plant. With more DNases available and the innovative use of defense gene (PR gene) promoters, the better genetic engineers will be able to utilize this window.

The premise of this analysis is that the universality of fungal DNases, especially the mitochondrial DNases, provides one explanation to account for why many of the fungi in the environment trigger plant defenses, whether by design or inadvertently. Although this signal is only one component of the events that are involved in pathogenicity, the DNases may be a major component affording plant tissue the long-recognized ability to resist many

TABLE 5. Effect of yeast DNase activity on the growth of Fusarium solani f. sp. pisi in vitro ${ }^{\mathrm{a}}$

\begin{tabular}{|c|c|c|c|c|c|}
\hline \multirow[b]{2}{*}{ DNase activity (units) } & \multicolumn{2}{|c|}{ Fract. 3} & \multicolumn{2}{|c|}{ Fract. 4} & \multirow[b]{2}{*}{ Growth without enzyme } \\
\hline & Rep 1 & Rep 2 & Rep 1 & Rep 2 & \\
\hline 160 & 0 & 0 & 0 & 0 & ++++ \\
\hline 80 & 0 & 0 & $\operatorname{Tr}$ & $\operatorname{Tr}$ & ++++ \\
\hline 40 & 0 & $\operatorname{Tr}$ & $\operatorname{Tr}$ & 0 & ++++ \\
\hline 20 & 0 & $\operatorname{Tr}$ & $\operatorname{Tr}$ & $\operatorname{Tr}$ & ++++ \\
\hline 10 & 0 & $\operatorname{Tr}$ & $\operatorname{Tr}$ & $\operatorname{Tr}$ & ++++ \\
\hline 5 & + & + & $\operatorname{Tr}$ & $\operatorname{Tr}$ & ++++ \\
\hline 2.5 & + & + & + & + & ++++ \\
\hline 1.2 & +++ & ++ & 0 & + & ++++ \\
\hline 0.6 & +++ & ++ & ++ & ++ & ++++ \\
\hline 0.3 & +++ & +++ & ++ & ++ & ++++ \\
\hline
\end{tabular}

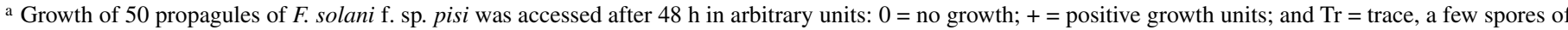
the total inoculum germinated. Vogel's medium ( $50 \mu \mathrm{l}$ in each dilution well) was supplemented with the indicated yeast DNase units. The DNase was recovered from the peak activity fraction of the Superdex 75 separation (see Materials and Methods). One enzyme unit digests $0.2 \mu \mathrm{g}$ of plasmid DNA in 10 min. 
fungal pathogens in a "nonhost resistance" manner. Finally, the SignalP, N-terminal amino acid sequence is an established mechanism for transiting membranes and may also assist entrance of the associated protein into the plant cell (13).
The molecular basis of the subsequent induction process relative to DNA damage within the plant tissue is only partially resolved and has been addressed previously $(18,19)$. Elicitors capable of targeting DNA $(5,15)$ can initiate the activation of PR
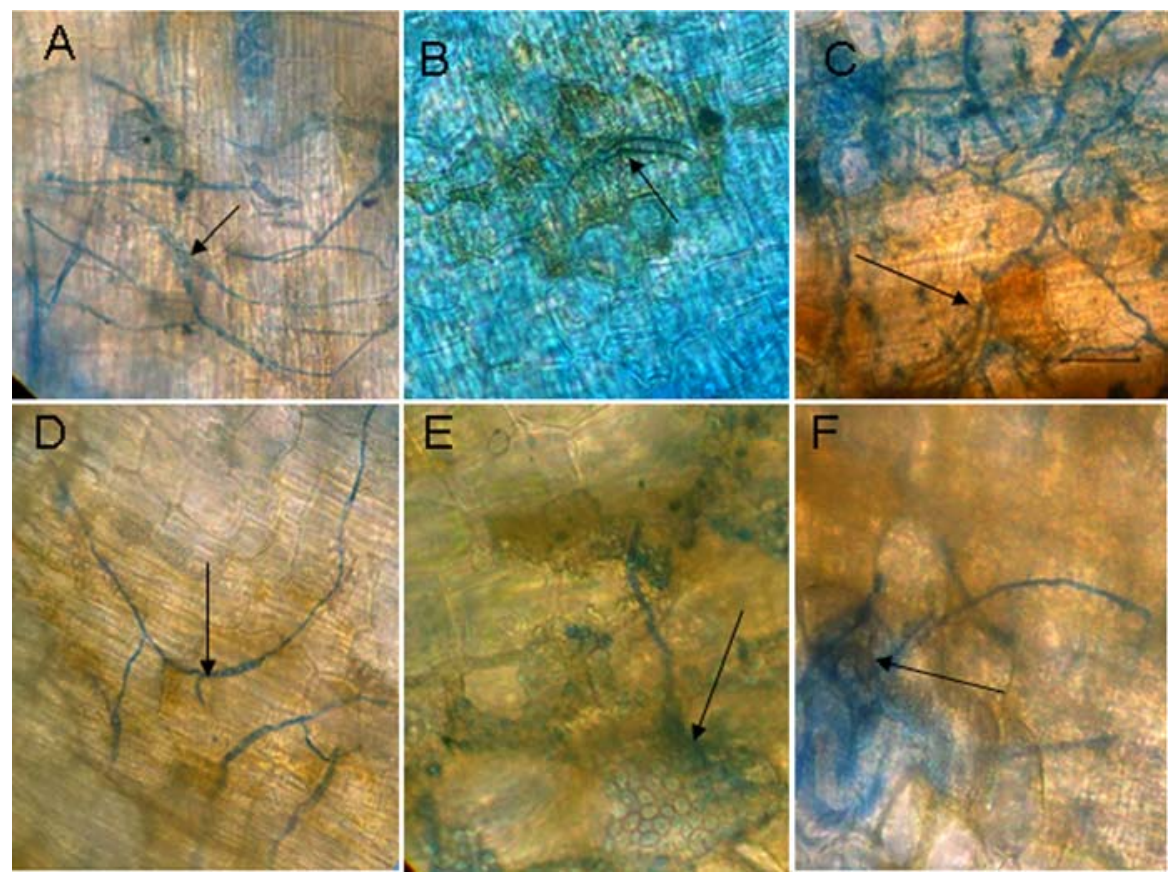

Fig. 6. Pretreatments to pea endocarp tissue enhance disease resistance against Fusarium solani f. sp. pisi. Experiment 1: A, $5 \mu$ of water; B, 16 units of yeast DNase, see Figure 5, Superdex fraction 5); or $\mathbf{C}, 4$ units of yeast DNase were applied per pod half 30 min prior to the application of $2.5 \mu l$ of a suspension of $F$. solani f. sp. pisi at $1 \times 10^{5}$ microconidia/ml. Experiment 2 : $\mathbf{D}, 5 \mu \mathrm{l}$ of water and $\mathbf{E}, 5 \mu \mathrm{l}$ of yeast cells $\left(4.2 \times 10^{5} / \mathrm{ml}\right)$ applied $30 \mathrm{~min}$ prior to the application of $5 \mu \mathrm{l}$ of $F$. solani f. sp. pisi spores. Experiment 3: F, Calf thymus DNase 1 ( 0.6 Fermentas units) followed in 20 min with the inoculation with $5 \mu$ l of $F$. solani f. sp. pisi at $1 \times 10^{6}$ spores $/ \mathrm{ml}$. Endocarp surface sections were stained with cotton blue and photographed at $48 \mathrm{~h}$ (A to E) and $72 \mathrm{~h}(\mathrm{~F})$. Bar $=45 \mu \mathrm{m}$. Arrows locate the original macroconidia.
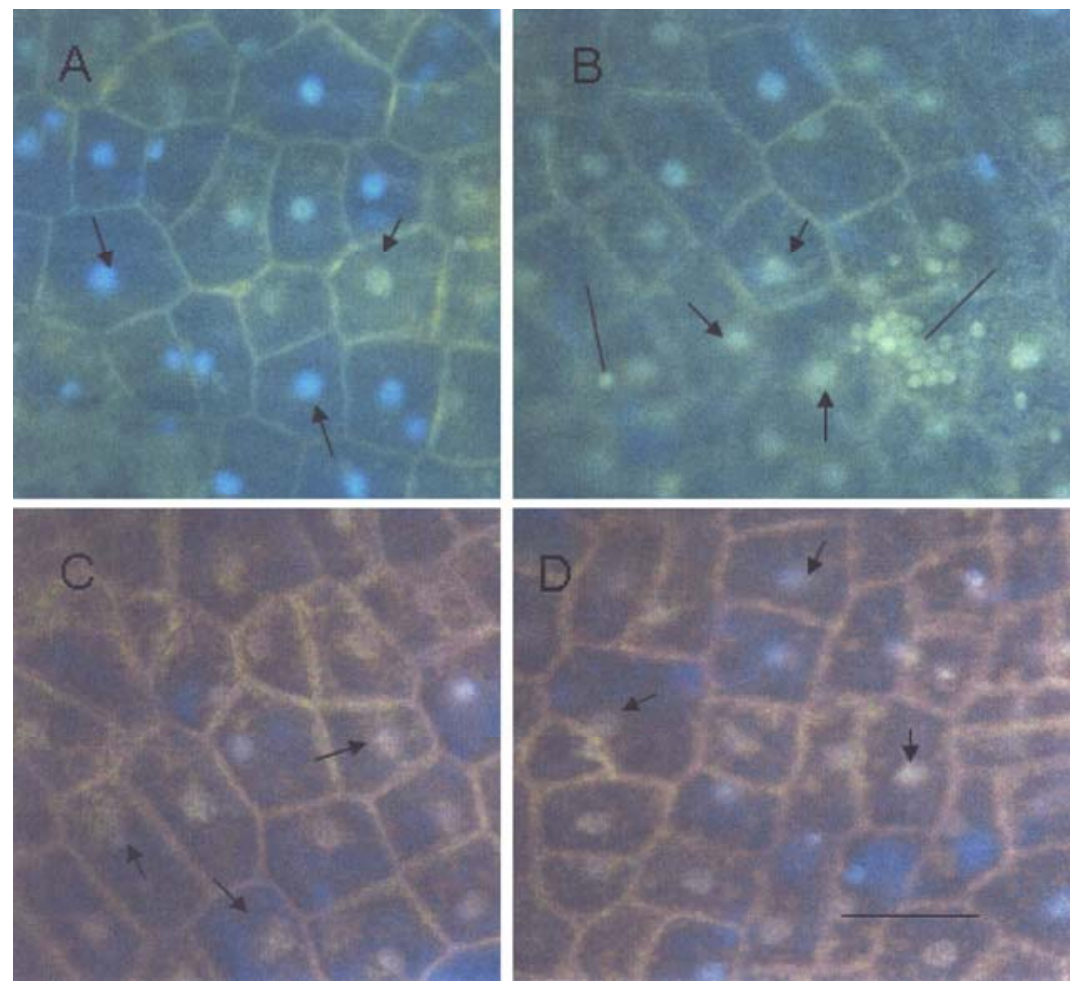

Fig. 7. Alteration of pea nuclei $3 \mathrm{~h}$ after treatment ( $10 \mu \mathrm{l}$ per pod half) with $\mathbf{A}$, water; $\mathbf{B}, 8 \times 10^{7}$ yeast cells; $\mathbf{C}$, yeast DNase (10 units per pod half); and $\mathbf{D}$, yeast DNase ( 1 unit per pod half). Nuclei of endocarp surface sections were stained with 4',6-diamidino-2-phenyliadole $(1 \mathrm{mg} / \mathrm{ml})$ and photographed and the fluorescence activated under UV light at high-power magnification. Arrows identify some nuclei and the lower end of solid lines (B) point to yeast cells. Photographs were uniformly enlarged in a printer and diameters of 30 nuclei per field determined by direct measurements. Average nuclei diameters for the treatments: $\mathrm{A}=10.0 \mu \mathrm{m}, \mathrm{B}=10.5 \mu \mathrm{m}, \mathrm{C}=11.57 \mu \mathrm{m}$, and $\mathrm{D}=11.2 \mu \mathrm{m}$. 
genes by multiple mechanisms, most of which alter transcription factors or the conformation of the nucleosome structure itself. Among these effects are those that can change the nucleosome directly (1), or temporarily juxtapose barriers such as histones $\mathrm{H} 2 \mathrm{~A}$ and $\mathrm{H} 2 \mathrm{~B}$ (18) that stall the progression of the DNA polymerase complex (25). The nuclei within F. solani f. sp. phaseoliinoculated pea tissue rapidly decrease in density (14). This suggests that the $F$. solani f. sp. phaseoli DNase, which produces single-strand nicks in pea DNA (19), loosens regions of the chromosomes enabling the transcription of defense genes. Finally, the current theory suggests that it is likely that many other fungal nucleases share this potential to activate defense genes.

\section{ACKNOWLEDGMENTS}

PPNS 0565, Department of Plant Pathology, College of Agricultural, Human, and Natural Resource Sciences, Agriculture Research Center, Project Number 1844, Washington State University. We thank X. Chen and P. Okubara, United States Department of Agriculture-Agricultural Research Service for reviewing the manuscript.

\section{LITERATURE CITED}

1. Adkins, M. W., and Tyler, J. K. 2006. Transcriptional activators are dispensable for transcription in the absence of Spt6-mediated chromatin re-assembly of promoter regions. Mol. Cell 21:452-453.

2. Bendtsen, J. D., Nielsen, H., Von Heijne, G., and Brunak, S. 2004. Improved prediction of signal peptides: SignalP 3.0. J. Mol. Biol. 340:783-795.

3. Chang, M.-M., Chiang, C. C., Martin, M. W., and Hadwiger, L. A. 1993. Expression of a pea disease resistance response gene in the potato cultivar shepody. Am. Potato J. 70:635-647.

4. Chiang C. C., and Hadwiger, L. A. 1980. Cloning and characterization of a disease resistance response gene in pea inducible by Fusarium solani. Mol. Plant-Microbe Interact. 3:78-85.

5. Choi, J. J., Klosterman, S. J., and Hadwiger, L. A. 2001. A comparison of the effects of DNA-damaging agents and biotic elicitors on the induction of plant defense genes, nuclear distortion and cell death. Plant Physiol. 125:752-762.

6. Choi, J. J., Klosterman, S. J., and Hadwiger, L. A. 2004. A promoter from pea gene DRR206 is suitable to regulate an elicitor-coding gene and develop disease resistance. Phytopathology 94:651-660.

7. Coleman, J. J., Rounsley, S. D., Rodriguez-Carres, M., Kuo, A., Wasmann, C. C., Grimwood, J., Schmutz, J., Taga, M., White, G.J., Zhou, S., Schwartz, D. C., Freitag, M., Ma, L. J., Danchin, E. G., Henrissat, B., Coutinho, P. M., Nelson, D. R., Straney, D., Napoli, C. A., Barker, B. M., Gribskov, M., Rep, M., Kroken, S., Molnar, I., Rensing, C., Kennell, J. C., Zamora, J., Farman, M. L., Selker, E. U., Salamov, A., Shapiro, H., Pangilinan, J., Lindquist, E., Lamers, C., Grigoriev, I. V., Geiser, D. M., Covert, S. F., Temporini, E., and VanEtten, H. D. 2009. The genome of Nectria haematococca: Contribution of supernumerary chromosomes to gene expansion. J. PLoS Genet. 5:E1000618.

8. Coleman, J. J., White, G. J., Roddriguez-Carres, M., and VanEtten, H. D. 2011. An ABC transporter and a cytochrome P450 of Nectria haematococca MPVI are virulence factors on pea and are the major tolerance mechanisms to the phytoalexin pisatin. Mol. Plant-Microbe Interact. 24:368-376.

9. Eichmann, R., Schultheiss, H., Kogel, K.-H., and Huckelhoven, R. 2004. The barley apoptosis suppressor homologue BAX inhibitor-1 compromises nonhost penetration resistance of barley to the inappropriate pathogen Blumeria graminis f. sp. tritici. Mol. Plant-Microbe Interact. 17:484-490.
10. Fristensky, B., Horovitz, D., and Hadwiger, L. A. 1988. cDNA sequences for pea disease resistance response genes. Plant Mol. Biol. 11:713-715.

11. Gerhold, D. L., Pettinger, A. J., and Hadwiger, L. A. 1993. Characterization of a plant stimulated nuclease from Fusarium solani. Physiol. Mol. Plant Pathol. 43:33-46.

12. Hadwiger, L. A. 2008. Pea-Fusarium solani interactions contributions of a system toward understanding disease resistance. Phytopathology 98:372-379.

13. Hadwiger, L. A. 2009. Localization predictions for gene products involved in non-host resistance responses in a model plant/fungal pathogen interaction. Plant Sci. 177:257-265.

14. Hadwiger, L. A., and Adams, M. J. 1978. Nuclear changes associated with the host-parasite interaction between Fusarium solani and peas. Physiol. Plant Pathol. 12:63-72.

15. Hadwiger, L. A., Chang, M.-M., and Parsons, M. A. 1995. Fusarium solani DNase is a signal for increasing expression of nonhost disease resistance response genes, hypersensitivity, and pisatin production. Mol. Plant-Microbe Interact. 8:871-879.

16. Hahn, M. G., and Albersheim, P. 1978. Host-pathogen interactions: XIV. Isolation and partial characterization of an elicitor from yeast extract. Plant Physiol. 62:107-111.

17. Hartney, S., Carson, J., and Hadwiger, L. A. 2007. The use of chemical genomics to detect functional systems affecting the non-host disease resistance of pea to Fusarium solani f. sp. phaseoli. Plant Sci. 172:45-56.

18. Isaac, J., Hartney, S. L., Druffel, K., and Hadwiger, L. A. 2009. The nonhost disease resistance response in peas; alterations in phosphorylation and ubiquitination of HMG A and histones H2A/H2B. Plant Sci. 177:439449.

19. Klosterman, S. J., Chen, J., Choi, J. J., Chen, E. E., and Hadwiger, L. A. 2001. Characterization of a $20 \mathrm{kDa}$ DNase elicitor from Fusarium solani f. sp. phaseoli and its expression at the onset of induced resistance in Pisum sativum. Mol. Plant Pathol. 2:147-158.

20. Lum, G., and Min, J. X. 2011. FunSecKB: The fungal secretome knowledgebase. Database 2011:1-10, bar 001. Online publication. doi:10.1093/database/bar001

21. Mentlak, T. A., Kombrink, A., Shinya, T., Ryder, L. S., Otomo, I., Saitoh, H., Terauchi, R., Nishizawa, Y., Shibuya, N., Thomma, B. P. H. J., and Talbot, N. J. 2012. Effector-mediated suppression of chitin-triggered immunity by Magnaporthe Oryzae is necessary for rice blast disease. Plant Cell 24:322-335.

22. Shibuya, N., and Minami, E. 2001. Oligosaccharide signaling for defence responses in plant. Physiol. Mol. Plant Pathol. 59:223-233.

23. Vogel, H. J. 1956. A convenient Medium for Neurospora. Microbiol. Genet. Bull. 13:43-44.

24. Watkins, W. T., and Hadwiger, L. A. 1998. A nuclease released from Colletotrichum coccodes is a defence gene elicitor. Mycol. Res. 102:167173.

25. Weake, V. M., and Workman, J.L. 2008. Histone ubiquitination triggering gene activity. Mol. Cell 29:653-663.

26. Wen, F., White, G. J., VanEtten, H. D., Xiong, Z., and Hawes, M. C. 2009. Extracellular DNA is required for root tip resistance to fungal infection. Plant Physiol. 151:820-829.

27. Wexler, M., Sargent, F., Jack, R. L., Stanley, N. R., Bogsch, E. G., Robinson, C., Berks, B. C., and Palmer, T. 2000. TatD is a cytoplasmic protein with DNase activity. No requirement for TatD family proteins in sec-independent export. J. Biol. Chem. 275:16717-16722.

28. Wolpert, T., Shiraishi, T., Collmer, A., Akimitsu, K., and Glazebrook, J. 2011. Genome-Enabled Analysis of Plant-Pathogen Interactions. American Phytopathological Society, St. Paul, MN.

29. Yin, C., Chen, X., Wang, X., Han, Q., Kang, Z., and Hulbert, H. 2009. Generation and analysis of expression sequence tags from haustoria of the wheat stripe rust fungus Puccinia striifromis f. sp. tritici. BMC Genomics 10:6236-637. 